\title{
Why is delirium more frequent in the elderly?
}

\author{
Orso Bugiani ${ }^{1}$
}

Received: 9 February 2021 / Accepted: 17 May 2021 / Published online: 24 May 2021

(C) Fondazione Società Italiana di Neurologia 2021

\begin{abstract}
An aging-related reduction in the brain's functional reserve may explain why delirium is more frequent in the elderly than in younger people insofar as the reserve becomes inadequate to cover the metabolic requirements that are critically increased by stressors. The aim of this paper is to review the normal aging-related changes that theoretically compromise complex mental activities, neuronal and synaptic densities, and the neurocomputational flexibility of the functional reserve. A pivotal factor is diminished connectivity, which is substantially due to the loss of synapses and should specifically affect association systems and cholinergic fibres in delirious patients. However, micro-angiopathy with impaired blood flow autoregulation, increased blood/ brain barrier permeability, changes in cerebrospinal fluid dynamics, weakened mitochondrial performance, and a proinflammatory involution of the immune system may also jointly affect neurons and their synaptic assets, and even cause the progression of delirium to dementia regardless of the presence of co-existing plaques, tangles, or other pathological markers. On the other hand, the developmental growth in functional reserve during childhood and adolescence makes the brain increasingly resistant to delirium, and residual reserve can allow the elderly to recover. These data support the view that functional reserve is the variable that confronts stressors and governs the risk and intensity of and recovery from delirium. Although people of any age are at risk of delirium, the elderly are at greater risk because aging and age-dependent structural changes inevitably affect the brain's functional reserve.
\end{abstract}

Keywords Aging $\cdot$ Brain $\cdot$ Delirium $\cdot$ Functional reserve

\section{Introduction}

In 2006, Speciale et al. [1] raised the question as to whether delirium, an "enormously impactful syndrome" [2] and a subject of semantic and research confusion [3, 4] since it was first described more than two thousand years ago, is a marker of brain fragility due to aging. This question was partially answered by the European Delirium Association and American Delirium Society [5], which established that delirium "is unquestionably a marker of [brain] vulnerability". However, the relationship between brain vulnerability and aging has not been addressed with as much resolution probably because it is considered obvious given the phenomenology of aging, and so how aging may make the brain more susceptible to delirium is still a matter of speculation.

Orso Bugiani

orso.bugiani@gmail.com

1 Istituto Neurologico Carlo Besta, Milan, Italy
The aim of this paper is to consider the changes that occur in the brain during normal aging. It is assumed that these changes reduce the brain's functional reserve, thus causing the fragility that may evolve into delirium more frequently in the elderly than in the young. In hospitalised subjects, the risk of delirium may increase from $3 \%$ in the young to $14 \%$ and $36 \%$ in the elderly aged $64-74$ years and over [6]: i.e. about $2 \%$ per year after the age of 65 years [7].

\section{Functional reserve and delirium}

According to most experts, delirium is a confusional syndrome ("an acute disorder of attention and cognition") [8] that develops because of the action of various stressors on fragile brain structures and their connections. Stressors act on nerve and glial cell systems via metabolic mediators, such as low energy levels following hypoxia, hypoglycemia and respiratory chain impairments, endo- and exotoxins, antibodies and autoantibodies, unbalanced ions, $\mathrm{pH}$ and osmolarity, drugs, and undue quantities of substantial metabolites and hormones. 
It is probably the balance between stressor strength and brain resilience that governs the risk and intensity of and recovery from delirium. Intuitively, brain resilience depends on the brain's functional reserve, which diminishes with aging: as summarised by Inouye et al. [9] "delirium may serve as a marker of the vulnerable brain with diminished reserve capacity".

The brain's functional reserve has been defined as "the remaining capacity [of the brain] to fulfil its physiological activity, [particularly] in the context of disease [...] or impairment" [10] of the brain itself and any organ or body system influencing its metabolism. Functional reserve is due to the interaction of complex mental activities, neural and synaptic densities, and neurocomputational flexibility [11], and may depend on the balance between brain connectivity and adaptive plasticity $[12,13]$, and the brain structures and energy available at any given moment. This suggests that the increased vulnerability of the elderly to delirium is because they have less functional reserve than the young [14]. According to the homeostenosis theory of the aging-related decline in reserve [15], which "matches the observation that the typical organ does not lose visible function so much as it loses measurable reserve" [16], delirium emerges when the reserve can no longer compensate for the effect of stressors. This view fits the conclusions of a meta-analysis of functional magnetic resonance imaging (fMRI) studies that the risk of delirium is related to the reduced structural connectivity of fragile networks, whereas the onset and course of clinical signs follow incidental dysfunctions of residual networks [17-19]. The question raised by Speciale et al. [1] may therefore be fully answered by considering aging-related structural and functional changes in the brain. Intuitively, the most relevant of these are changes in neuritic wiring and connectivity, cerebral blood flow (CBF), the blood-brain barrier (BBB), the dynamics of cerebrospinal fluid (CSF), the respiratory chain, and native immunity, which may also represent the postulate for some of the hypotheses concerning the origin of delirium [4, 20, 21]. Moreover, as might be expected, the effect of aging on functional reserve may be potentiated by the severity of concomitant diseases, pre-existing cognitive impairment, and reduced vision and hearing [22].

\section{Aging-related brain changes, functional reserve, and delirium (Tables 1 and 2)}

\section{Connectivity}

Brain shrinkage is a gross outcome of normal aging. The extent of the shrinkage was long debated until Fotenos et al. [23] used magnetic resonance imaging (MRI) to measure brain volume in 362 non-demented subjects aged 18-93 years and found that, after adjusting for head size, it was inversely related to age and was $0.22 \%$ per year $(0.40 \%$ in the elderly). This study confirmed the findings of a previous study of 465 healthy subjects aged 18-79 years that revealed grey matter attenuation, particularly in the anterior cingulate, central, and angular gyri [24]. Shrinkage is due to cellular and sub-cellular changes, such as shortening dendritic branches [25], the loss of dendritic spines [26] and synapses [27], the shrinkage of large pyramidal neurons [28], the contraction of axonal fields [29], and centrum ovale re-modelling leading to a $45 \%$ loss of myelinated axons by the age of 80 years [30]. Although less dramatic than once believed $[31,32]$ and variably distributed $[33,34]$, these changes concur with lesions conventionally attributed to pathology ( $\beta$-protein deposits in neuropil and vessel walls, neuronal and glial phospho-tau tangles, $\alpha$ synuclein and TDP43 protein immunoreactive neurons, senile plaques [35], hippocampal sclerosis, micro-infarcts, and microbleeds) to reduce neuronal connectivity [36], energy metabolism [37], and neurotransmitter levels [4, 20]. Salthouse [38] looked for a relationship between cognitive decline and age-dependent changes, particularly MRI hyperintensities, and found that at most it was only weak. However, although this conclusion is in line with the concept of an asymptomatic burden of structural changes in brains that have aged cognitively well, as suggested by observations in the oldest old [39], it does not argue against the possibility that the changes may become symptomatic because of the action of stressors that absorb the functional reserve. In this regard, the interactions between changes and stressors may be expressed by the stressor-to-synapse ratio, which is expected to increase with aging.

Table 1 Aging-related brain changes

A. Morpho-functional changes peculiar to aging

1. Reduced

a. Neural connectivity due to shortening dendritic branches, with the loss of dendritic spines and synapses, the contraction of axonal fields, and the loss of myelinated axons, all revealed by decreased neurotransmitter and neurohormone levels

b. Cerebral blood flow due to micro-vessel stiffening, reduced vessel density, and deficient autoregulation

c. Respiratory chain efficiency

2. Increased blood-brain barrier permeability following changes in neurovascular components

3. Remodelled

a. Cerebrospinal fluid dynamics, with an increased fluid-to-brain volume ratio

b. Immunosurveillance leading to the pro-inflammatory status of microglia and macrophages

B. Incidental structural lesions common to diseases

a. Protein overload in cells, the neuropil, and vessel walls, with neuritic dystrophy and degeneration

b. Micro-infarcts and micro-bleeds 
Table 2 Principal targets of morpho-functional changes in aging brain and their delirium-related effects $(\rightarrow)$

There has been a long debate about which brain structures are the most vulnerable. Meynert [40] and Bonhoeffer [41] attributed delirium to the fragility of the thalamic and association systems supporting sensory perceptions, whereas Lipowski [42] and Plum and Posner [43] regarded delirium as a state of altered consciousness, thus implying that the main target was the brainstem activating system. Later, based on a longitudinal study of 100 delirious subjects ( 27 of whom were demented), Leonard et al. [44] maintained that delirium was the consequence of a thalamus-mediated cortical impairment, consistent with the slowing of electroencephalographic tracings [45, 46] and a global reduction in CBF [47, 48], whereas McLott et al. [49] speculated that post-operative delirium was related to abnormalities in thalamic inputs to the amygdala, hypothalamus, and periaqueductal grey matter. However, diffusion tensor imaging MRI (DTIMRI) allowed Cavallari et al. [50] to show that inter-hemispheric and fronto-thalamocerebellar networks were the most involved in patients with post-operative delirium. Trzepacz [51], who analysed functional and imaging studies of psychiatric patients and delirious patients sharing the same symptoms, reached more varied conclusions and suggested that the right or left prefrontal cortex, the anterior and right thalamus, or the right basilar mesial temporoparietal cortex may cause the core symptoms of delirium (e.g. disorientation, cognitive and language defects, a disordered sleep-wake cycle, disorganised thinking), whereas the ancillary symptoms (delusions, hallucinations, illusions, affective lability) depend on the causative disease. On the other hand, theories about the brain being organised into opposing resting- and task-positive networks [52] gave Sanders [53] the idea that delirium is due to abnormalities in their functional relationships. The structures active at rest include the postero-medial cortex, the medial pre-frontal cortex, and temporo-parietal junctions, whereas those activated by tasks include the posterior cingulate gyrus and the precuneus, dorso-, and ventrolateral pre-frontal cortex; the insula; and supplementary motor areas. Using fMRI, Choi et al. [54] found that rest- and task-activated structures were not functionally opposed in delirious subjects as they were in normal subjects and patients after recovery. Furthermore, some subcortical structures (the intralaminar thalamus, the striatum, the tegmentum, and the basal nucleus) were variably involved.

Changes in neurotransmitter balance, the sleep-wake cycle, and stress response dynamics have also been considered in the search for the more fragile structures. Reactions to stress start from the hippocampus and hypothalamus and, via the autonomic nervous system and pituitary gland, force the adrenal glands to increase noradrenaline and cortisol secretion (hence the definition of the hypothalamic-pituitary-adrenal [HPA] axis) to provide the body and mind with anti-stress support $[55,56]$. In the limbic system (CA1 and CA3 hippocampus, dentate gyrus, basolateral amygdala) and medial pre-frontal and orbital frontal cortex (the most widely studied in laboratory animals for the presence of specific receptors), glucocorticoids may foster dendritic circuitry and modulate neurogenesis, but become neurotoxic over time. The shrinkage of the hippocampus, amygdala, and frontal cortex in the normal elderly and demented patients has been attributed to chronic stress and cortisol neurotoxic activity, but neurodegeneration could modify the cortisol set-up [57], increase diurnal cortisol secretion [58], and cause abnormal stress responses. On these grounds, MacLullich et al. [59] speculated that delirium may be due to stress responses that become harmful after HPA axis dysregulation possibly caused by inflammatory mediators.

Acetylcholine, dopamine, glutamine, GABA, serotonin, noradrenaline, tryptophan, phenylalanine, and histamine levels are decreased in the normal elderly [4, 20], and unbalanced in delirious patients [60]. Delirium is most frequently associated with reduced acetylcholine levels, excess dopamine, noradrenaline, and/or glutamate release, or uneven amounts in serotonin, histamine, and $\gamma$-aminobutyric acid [19]. However, cholinergic deficiency [61] has so far been the most widely accepted because of the confusional state caused by anti-cholinergic drugs and the possibility of 
recovery by means of cholinergic agents. A variant hypothesis based on an imbalance between cholinergic and adrenergic neurotransmitters has been suggested by Itil and Fink [62], who maintained that hyperactive forms are due to a prevalence of noradrenergic systems. A dopamine to acetylcholine imbalance might also be involved [51], as suggested by the existence of delirium due to opioids and drugs that promote dopamine release, and the anti-delirium efficacy of neuroleptic drugs that compete with dopamine. Guo et al. [63] have even suggested that glutamate-glutamine cycle dysfunction may explain post-surgical delirium. Multiple defects may lead to contrasting effects [64] as in the case of the susceptibility to delirium of Parkinsonian patients who have a prevalence of cholinergic over dopaminergic and monoaminergic neurons. In comparison, the normal elderly can rely on fewer striatal dopamine receptors balancing residual nigral neurons [65-67]: this lasting balance can appropriately support extrapyramidal functions under basal conditions, but it cannot easily combat stressors such as fever, infections, and neuroleptics.

The reduced duration, continuity, and quality of sleep in the old age $[68,69]$ all increase the risk of delirium. They are associated with lower levels of melatonin and structural changes in the networks supporting the sleep-wake cycle by means of circadian melatonin release [70], although this might be increased in hypoactive delirious patients [71]. Among the involved structures, Zhong et al. [72] listed the retinalhypothalamic tract, the suprachiasmatic and galaninergic ventrolateral preoptic nuclei regulating the melatonin clock, orexinergic neurons in the hypothalamus, brainstem monoaminergic nuclei, hemispheric white matter, and the prefrontal cortex. However, sleep deprivation is supposedly responsible for so many dysfunctions [73, 74] that it may contribute to causing delirium [75] before becoming one of its leading symptoms.

\section{Blood flow}

CBF decreases with age [76] and, according to Amin-Hanjani et al. [77], who analysed MRI angiograms of 325 healthy subjects aged 18-84 years, and Zhang et al. [78], who used arterial spin labelling MRI (ASL-MRI), the reduction amounts to $2.6 \mathrm{~mL} / \mathrm{min}$ and $0.38-0.45 \%$ every year. Aging also affects CBF autoregulation: i.e. the ability to compensate for blood pressure fluctuations and provide the brain with constant rates of oxygen and glucose by means of arterioles that shrink and expand in response to nervous and chemical inputs [79]. Aging could affect the neurons that regulate vascular tone (bipolar nerve cells in sub-cortical white matter and projections from the locus coeruleus, raphe, tegmentum, and nucleus basalis) [80, 81], and also affect autoregulation as a result of structural alterations in arterioles and capillaries, such as the attenuation of the endothelium with loss of mitochondria, changes in connective tissue and smooth muscle fibres, the thickening of basement membranes, microglia and pericyte proliferation, the decreased expression of water channels in astrocytic feet $[82,83]$, and $\beta$-protein overload. Additional modifications such as vessel tortuosity and collagenosis, string segments in the white matter [84], hyalinisation of vessel walls due to arteriolosclerosis and lipo-hyalinosis $[85,86]$, and the enlargement of perivascular spaces following an increased pulse rate indicate wall stiffening [87], which impairs the elastic reservoirs of pulse energy [88] and contributes to slowing CBF $[79,89]$. These changes may be relevant to brain reserve insofar as they increase the risk of tissue hypoxia, metabolic stress, and nerve cell death [90] when blood pressure drops critically and, in the absence of autoregulation, prevents CBF from fulfilling tissue metabolic requirements. An additional risk may come from vessel density, which decreases with aging [91] despite attempts of capillary regrowth and repair [82], and the characteristics of some intraparenchymal vessels: for example, a narrowing lumen of long penetrating arteries might predispose to chronic periventricular hypoxia, which can be revealed by MRI as leukoaraiosis. Nevertheless, the weight of MRI hyperintensities as a risk marker of delirium in selected surgical patients [92-94] has been questioned [95]. Likewise, an association between delirium and global or regional CBF abnormalities revealed by ASL-MRI before surgery proved to be doubtful [96], although low levels of cerebral oxygen saturation have been found to predict delirium after cardiac surgery in aged, neurologically impaired, or chronically hypoxic subjects [97].

\section{Blood-brain barrier}

Aging-related capillary changes affect the efficacy of the $\mathrm{BBB}$, a neurovascular unit consisting of endothelial cells lying on a membrane surrounded by astrocytic feet, pericytes, nerve cell terminals, and microglia [98]. The tight junctions between endothelial cells, and cell-specific functions allow the BBB to act as an intercellular gate for water-soluble molecules and trans-cellular transfer machine for lipophilic agents, molecules carried by proteins, and substances that cross cells via receptors and vesicles [99-101]. In addition, astrocytes mediate metabolic traffic between blood and neurons [102], whereas pericytes control capillary flow [103]. Any changes in the neurovascular unit affect its functional coupling and lead to inaccurate permeabilities that challenge brain tissue and interstitial fluids with abnormal concentrations of ions, metabolites, and substances that otherwise remain or are transferred outside the brain. Erickson and Banks [104] have drawn attention to the reduced expression of proteins carrying glucose and insulin into the brain and $\beta$-protein outwards, and the increased intracerebral diffusion of plasma proteins through 
inter-cellular clefts. $\beta$-protein overload may also contribute to BBB breakdown [105].

The CSF-to-plasma albumin ratio has usually been used to follow the increase in BBB permeability during aging [106]. A dynamic contrast-enhanced MRI study of 113 cognitively normal subjects aged 21-83 years by Senatorov et al. [107] found that the increase begins in mid-life, and Chen et al. [108] have calculated that, in comparison with young barriers that can stop proteins with a molecular weight of $>91.9 \mathrm{kDa}$, elderly barriers can be crossed by heavier molecules of up to $120 \mathrm{kDa}$. Some capillaries are more vulnerable to permeability failure than others, thus suggesting where BBB dysfunction may start. Montagne et al. [109] measured the MRI gadolinium blood-to-brain transfer constant in 24 non-demented subjects aged 23-91 years and found that BBB permeability increases with age in the capillaries of CA1 and the dentate gyrus of the hippocampus, but not in the capillaries of CA3 or other regions. According to Nation et al. [110], hippocampal BBB permeability is even more compromised in subjects with mild cognitive impairment and a CSF load of sPDGFR $\beta$, a growth factor involved in angiogenesis but also a marker of pericyte damage. This suggests that pericytes might be the first victims of BBB breakdown, although it is the whole unit that suffers structural modifications during aging. Erdö et al. [111] have reviewed the literature on this point and listed a loss of endothelial cells, a reduction in the number of endothelial mitochondria and the expression of tight junction proteins (occludin, claudin, immunoglobulin), a thickening of the basement membrane coupled with decreased laminin content and increased collagen IV and agrin, abnormal bodies and larger mitochondria in the cytoplasm of pericytes, astrocytosis with glial fibrillary acidic protein overexpressed in astrocytic feet, and amoeboid microglia expressing pro-inflammatory mediators. Similar changes have been reproduced in models of BBB breakdown. Varatharaj and Galea [112] have reviewed studies of the pro-inflammatory effects of lipopolysaccharides on cell cultures and laboratory animals, and indicated abnormalities in transporters, prostaglandins, cytokines, tight junctions, astrocytes, and endothelial surfaces. Acharya et al. [113] reported that flurane anaesthetics can damage the proteoglycans and sialoproteins contained on the endothelial surfaces of laboratory animals and increase BBB permeability to plasma proteins. These changes were much more severe and lasted longer in older animals, which suggests that fluranes may be involved in post-surgical delirium in the elderly.

\section{Cerebrospinal fluid}

Aging-related changes in CSF have been attributed to oxidative damage and atrophy of the ependymal cells covering plexus and ventricles, and degeneration of the plexus vascular stems [114]. Each of the various components of CSF dynamics [115] is susceptible to senescence: its formation rate $(500-600 \mathrm{~mL} /$ day is filtrated and secreted via the choroid plexus, ependyma, BBB, arachnoid surface, and modulated by endocrine mechanisms), pressure $\left(100 \mathrm{~cm} \mathrm{H}_{2} \mathrm{O}\right)$, flow (pulsatile from the plexus to subarachnoid spaces), turnover rate (up to 4-fold daily), volume (160 mL inversely related to turnover and intra-cranial blood volume), composition (99\% water, with a very low protein content), sleep-related recycling via perivascular spaces and interstitial glymphatic networks, and reabsorption by lymphatic and venous streams. Combined with brain shrinkage, the overall effect of senescence on these parameters is an increase in the CSF-to-brain volume ratio $[116,117]$, which reflects reduced CSF formation $(-50 \%)$, turnover, recycling, and reabsorption, and increased protein and glucose content with higher osmolarity [118]. Ventricular enlargement can also be magnified by hypoxia because of the over-expression of aquaporin 4 , a water channel of pericapillary astrocytes that pumps water from the blood into interstitial spaces and may increase CSF water content $[119,120]$.

The findings of experimental studies [121, 122] indicate that aged CSF and changes in the BBB obstruct the adequate delivery of nutrients (glucose, vitamins, peptides, nucleosides, growth factors, etc.) to tissues via interstitial fluids and the total removal of harmful metabolites [123]. Particular attention has been paid to $\beta$-protein, which accumulates in grey matter during aging, particularly in subjects with Alzheimer's disease. This apparently neurotoxic accumulation is probably due to an imbalance in the activity of RAGE (a receptor for advanced glycation end products) and LRP-1 (low-density lipophilic receptor-associated protein 1), which reside in plexus epithelia and capillary endothelia [124]. The former moves $\beta$-protein from the blood into interstitial fluids and CSF, and the latter does the opposite $[125,126]$. Aging increases the expression of RAGE and decreases that of LRP-1 [127], and thus drives $\beta$-protein turnover towards accumulation. The generation of $\beta$-protein is stimulated by aging-related chronic hypoxia, glucose deprivation [128-130], and sleep dysfunctions $[131,132]$, and its neurotoxicity may be strengthened by the aging-related decreased expression of transthyretin, a protein that is secreted by plexus and binds and blocks $\beta$-protein $[114,133]$.

\section{Respiratory chain}

Aging impairs cellular respiration because of a mitochondrial dysfunction that lessens ATP production by $8 \%$ every ten years, and even more in sedentary, overweight subjects [134]. Furthermore, mitochondria cross reduced antioxidant defences and accumulate reactive oxygen species, thus leading to oxidative stress and the generation of mitochondrial DNA mutations, a loss of efficient energy metabolism, and metabolic changes that progress to cell degeneration and 
apoptosis. Harman [135] suggested that this process, which induces muscle volume to shrink from mid-life onwards, was the basic mechanism of aging but it is now regarded as just part of the involution of various interactive cell pathways [136]. However, it has been suggested that delirium is related to oxidative neuronal stress because oxygen saturation and catalase levels are consistently lowered in delirious postoperative patients $[137,138]$. Neurons are particularly vulnerable to mitochondrial impairment and anaerobic metabolism, and the consistently increased lactate levels in elderly brains due to mitochondrial involvement may be a marker of aging in general [139]. The hypoxic vulnerability of neurons is related to the fact that they depend on oxidative phosphorylation to satisfy their energy needs. A review by Grimm and Eckert [140] describes neurons as life-long cells that cannot retain the mitochondrial assets received at birth because of the failure of mitochondrial functions of paramount importance, such as fusion and fission dynamics, debris autophagy, and the ability to increase energy production when required. It is possible that mitochondrial vulnerability to aging is greater in the neuronal compartments that require more energy, particularly the synaptic terminals and axons at the level of the nodes of Ranvier, which suggests that mitochondrial aging is a critical event that consistently affects neuronal connectivity.

Little is known about the mitochondrial aging of glial cells or its neuronal effects, but Jiang and Cadenas [141] have reported increased energy production by astrocytes at the expense of neurons, which suggests that aging is associated with a detrimental change in the previously protective neurocentred functions of astrocytes.

\section{Microglia and macrophages}

The word "inflammaging" was coined by Franceschi et al. [142] to define the pro-inflammatory state of the immune system induced by life-long antigen pressure and stress [143], which can generate an immuno-senescence that favours the onset of aging-related diseases. This generalised involution also affects microglia (the resident immune cells that protect the brain against organic intruders) by eventually allowing them to develop a neurotoxic pro-inflammatory phenotype. According to Cornejo and von Bernhardi [144] and many others who have studied the subject [145-147], aging microglia are characterised by molecular changes (an increased expression of pro-inflammatory cytokines, inflammatory and toll-like receptors and signalling, a decreased expression of anti-inflammatory cytokines and the activation of inhibitory factors, and the overproduction of reactive oxygen species) that make them abnormally primed and unfit to do their work. The morphology and dynamics of senescent microglia are in line with changes in their younger functions $[148,149]$ as they show an increased propensity for proliferation and enlargement. Their cytoplasm is fragmented, and the residual processes are thicker, less ramified, and poorly reactive to extra-cellular signals of injury. These changes lead to exaggerated inflammatory responses and simultaneously impaired ability to catch and phagocyte intruders [150]. Two additional phenotypes (rod-shaped and dark microglia) have been described in elderly humans [151] and mice [152], but it is doubtful that they are pertinent to normal aging. Unlike microglia, brain macrophages derived from circulating monocytes become more anti-inflammatory and less prone to proliferation; however, they are functionally like aging microglia as they do not activate phagocytosis as effectively as when they were young [153]. In addition, a senescent BBB may interfere with their ability to cross vessel walls, which normally occurs at venule level. Conversely, increased BBB permeability allows plasma albumin to enter astrocytes and overactivate neurotoxic cytokines [107], particularly in patients whose peripheral inflammation is responsible for further endothelial and perivascular cell involvement [154]. Perry and Holmes [155] have underlined the role of $\beta$-protein and misfolded proteins in microglial priming, whereas Safaiyan et al. [156] have observed microglia that become senescent after accumulating membrane debris from myelin turnover.

"Inflammaging" implies that aging-related inflammation can promote delirium, and so cytokines capable of mediating the detrimental effect of stressors on the brain (and possibly modifying the release of neurotransmitters [157] and activating the HPA axis) $[55,158,159]$ may be markers of delirium. Peripheral inflammation and infections are powerful humoral and cell-mediated stressors that reach the brain via the blood and the vagus nerve and stimulate innate immune cells to produce pro-inflammatory cytokines $[160,161]$. Interleukin6 (IL-6) may be the best peripheral marker of delirium as it is not only detectable in plasma and CSF samples from delirious post-surgical and post-stroke patients [158, 162-167], but also in brain tissue together with markers of astroglial and microglial activation [168]; however, plasma and CSF Creactive protein, tumour necrosis factor $\alpha, \mathrm{IL}-1 \alpha$ and $1 \beta$, IL8, IL-10, and soluble IL-1 and IL-6 receptor antagonist levels may be equally important [169-174]. On the other hand, these diagnostic markers have no predictive value as they are undetectable before the onset of delirium [175].

\section{Comments}

This overview argues that senescence involves many entwined changes that deplete the structural and metabolic resources supporting cerebral functions and reserves, thus making the brain increasingly vulnerable to the progression of stress to a state of delirium without precluding recovery. The relationships between these magnitudes can be transformed into the proportion delirium : recovery $=$ stressor : reserve, which indicates that functional reserve and stressor 
strength are factors that act in opposition to each other to govern not only the individual risk and severity of delirium, but also the prospect of recovery, thus explaining why the aim of treating delirium is to weaken stressors and strengthen reserve.

If a decreasing reserve predisposes to delirium, residual reserve and the capacity to resist stressors may not only partially explain differences in individual resilience, but also allow the brain to recover. This was first pointed out by Meynert [40], who coined the word "amentia" to connote confusion as the clinical hallmark of delirium and underline the fact that, unlike dementia, delirium is not necessarily irreversible. Nevertheless, despite residual reserve, delirium can increase the risk of incident dementia [176, 177], accompany longterm cognitive decline [178], and worsen the severity of preexisting dementia $[179,180]$. Davis et al. [181, 182] have investigated whether the acceleration of cognitive decline in later life induced by delirium is influenced by the tangles, plaques, Lewy bodies, micro-infarcts, and micro-bleeds associated with aging that may cause late-onset dementia. Their study of 987 brain donors (mean age at death 90 years, median follow-up 5.2 years, 279 with delirium) showed that the conversion of delirium to dementia is not influenced by the burden of the lesions conventionally associated with dementia; they concluded that "additional [...] pathologic processes [should] specifically relate to delirium", and suggested inflammation as one of these. A complementary study by ErtenLyons et al. [183] investigated the progression of brain disease and atrophy in 71 elderly subjects and the authors concluded that the burden of Alzheimer-type and vascular lesions does not justify the amount of brain atrophy in patients with mild cognitive impairment and dementia, thus suggesting the involvement of other factors. These findings may argue against the conventional view that there is a continuum between normal aging and late-onset Alzheimer's disease based on the progression and increasing burden of plaques and tangles in both conditions [184] and support the pathogenic role of aging-related and stressor-mediated structural changes that are accelerated and increased by particularly severe, recurrent, and long-standing delirium. In other words, stressors may not only drain functional reserve and lead to the onset of delirium but, depending on their severity and the duration of delirium, simultaneously increase the burden of common aging-related changes in $\mathrm{CBF}, \mathrm{BBB}, \mathrm{CSF}$ dynamics, the respiratory chain, immunosurveillance, and, finally, connectivity. One example of the multiple consequences of even a single stressor on the aging brain is COVID-19 encephalopathy $[185,186]$.

The difficulty of assigning these changes a recognisable dimension is due to the difficulty of assessing and following them during life to identify traits that are comparable with those of dementia. However, some instrumental data have been obtained from delirious patients that are consistent with recovery or ongoing neurodegeneration. Yokota et al. [47] used xenon-enhanced computed tomography to measure $\mathrm{CBF}$ in delirious patients, and found that it was significantly reduced at the level of the frontal, temporal, and occipital cortex; the thalamus; and basal ganglia, but normalised after delirium regression, and Choi et al. [54] found that fMRI abnormalities involving the connections between the dorsolateral, prefrontal, and posterior cingulate cortex can disappear after recovery, although van Montfort et al. [16] used the same experimental design and found that functional abnormalities persisted. Sharshar et al. [187] have reported that MRI perivascular hyperintensities in the white matter of patients with septic shock had a poor outcome that was attributed to abnormally increased BBB permeability. Morandi et al. [188] studied the structure of corpus callosum and internal capsule white matter in 47 delirious patients by means of DTI-MRI and found that reduced fractional anisotropy values indicating white matter disruption persisted for a long time in association with worse cognitive scores. Similar changes were found by Cavallari et al. [189] in the periventricular, frontal, and temporal white matter of 25 subjects presenting cognitive decline one year after post-operative delirium. Prolonged delirium may be responsible for reduced frontal lobe and hippocampal volume [190], and worse global cognition and executive function scores after three and 12 months [5]. According to van Munster et al. [191], increased plasma levels of astrocytic protein S100 may be a marker of brain tissue damage in delirious patients.

\section{Concluding remarks}

Although elderly subjects are at much higher risk of delirium than the young, children and adolescents are also at high risk. A review by Hatherill and Flisher [192] has described prevalence rates of 17-66\% among referrals from paediatric intensive care units, and others have reported rates of 4-29\% and $13-44 \%[193,194]$. The size of the intervals has been attributed to methodological differences in diagnostic procedures [194, 195], but a complementary explanation might be age, given that delirium occurs more frequently in children aged $<5$ years and its prevalence peaks at 56\% [196] before the age of two years $[194,196]$. The reduction in the prevalence of delirium as children and adolescents become older indicates that the ongoing organisation of neuronal hierarchies in myelinogenetic cycles, and the maturation of barrier and ependyma, blood flow autoregulation, native immunity etc., allows functional reserve to increase during brain development as much as it decreases during aging following the onset and progression of structural and functional changes. Taken together, these data show a U-shaped distribution of brain vulnerability to delirium in relation to age, which reflects the availability of functional reserve and supports the relevance of its pathogenic role in lifetime delirium. 
Acknowledgements Dr. Kevin R. Smart is kindly acknowledged for reviewing the manuscript.

\section{Declarations}

Conflict of interest None

Ethical approval None

Informed consent None

\section{References}

1. Speciale S, Bellelli G, Turco R, Trabucchi M (2006) Il delirium: marker dell'evoluzione clinica di un anziano fragile affetto da patologia acuta? G Gerontol 54:28-40

2. MacLullich AM, Hall RJ (2011) Who understands delirium? Age Ageing 40:412-414

3. Bugiani O (2020) Deciphering delirium through semantics. A selective synopsis. Neurol Sci 42:2147-2151

4. Maldonado JR (2018) Delirium pathophysiology: an updated hypothesis of the aetiology of acute brain failure. Int J Geriatr Psychiatry 33:1428-1457

5. European Delirium Association; American Delirium Society (2014) The DSM-5 criteria, level of arousal and delirium diagnosis: inclusiveness is safer. BMC Med 12:141. https://doi.org/10. 1186/s12916-014-0141-2

6. Pandharipande PP, Girard TD, Jackson JC, Morandi A, Thompson JL, Pun BT, Brummel NE, Hughes CG, Vasilevskis EE, Shintani AK, Moons KG, Geevarghese SK, Canonico A, Hopkins RO, Bernard GR, Dittus RS, Ely EW, BRAIN-ICU Study Investigators (2013) Long-term cognitive impairment after critical illness. N Engl J Med 369:1306-1316

7. Pendlebury ST, Lovett NG, Smith SC, Dutta N, Bendon G, LloydLavery A, Mehta Z, Rothwell PM (2015) Observational, longitudinal study of delirium in consecutive unselected acute medical admissions: age-specific rates and associated factors, mortality and re-admissions. BMJ Open 5:e007808. https://doi.org/10. 1136/bmjopen-2015-007808

8. Oh ES, Akeju O, Avidan MS, Cunningham C, Hayden KM, Jones RN, Khachaturian AS, Khan BA, Marcantonio ER, Needham DM, Neufeld KJ, Rose L, Spence J, Tieges Z, Vlisides P, Inouye SK, NIDUS Writing Group (2020) A roadmap to advance delirium research: recommendations from the NIDUS Scientific Think Tank. Alzheimers Dement 16:726-733

9. Inouye SK, Westendorp RG, Saczynski JS (2014) Delirium in elderly people. Lancet 383:911-922

10. https://en.wiktionary.org/w/index.php?title:functionalreserve\&oldid= 41600298 (2016)

11. Valenzuela MJ (2008) Brain reserve and the prevention of dementia. Curr Opin Psychiatry 21:296-302

12. Gray DT, Barnes CA (2015) Distinguishing adaptive plasticity from vulnerability in the aging hippocampus. Neuroscience 309: $17-28$

13. Shafi MM, Santarnecchi E, Fong TG, Jones RN, Marcantonio ER, Pascual-Leone A, Inouye SK (2017) Advancing the neurophysiological understanding of delirium. J Am Geriatr Soc 65:11141118

14. Taffett GE (2006) Physiology of aging. In: Cassel CK (ed) Geriatric medicine: an evidence-based approach, 4th edn. Springer, New York, pp 27-35
15. Resnick NM (1994) Geriatric medicine. In: Isselbacher KJ, Braunwald E (eds) Harrison's principles of internal medicine, 13th edn. McGraw-Hill, New York, pp 30-36

16. Troncale JA (1996) The aging process. Physiologic changes and pharmacologic implications. Postgrad Med 99(111-114):120-122

17. van Montfort SJ, van Dellen E, van den Bosch AM, Otte WM, Schutte MJ, Choi SH, Chung TS, Kyeong S, Slooter AJ, Kim JJ (2018) Resting-state fMRI reveals network disintegration during delirium. Neuroimage Clin 20:35-41

18. van Montfort SJ, van Dellen E, Stam CJ, Ahmad AH, Mentink LJ, Kraan CW, Zalesky A, Slooter AJ (2019) Bain network disintegration as a final common pathway for delirium: a systematic review and qualitative meta-analysis. Neuroimage Clin 23: 100809. https://doi.org/10.1016/j.nicl.2019.101809

19. van Montfort SJ, Slooter AJC, Kant IM, van der Leur RR, Spies C, de Bresser J, Witkamp TD, Hendrikse J, van Dellen E (2020) fMRI network correlates of predisposing risk factors for delirium: a cross-sectional study. Neuroimage Clin 27:102347. https://doi. org/10.1016/j.nicl.2020.102347

20. Maldonado JR (2013) Neuropathogenesis of delirium: review of current etiologic theories and common pathways. Am J Geriatr Psychiatry 21:1190-1222

21. Wang Y, Shen X (2018) Postoperative delirium in the elderly: the potential neuropathogenesis. Aging Clin Exp Res 30:1287-1295

22. Inouye SK, Charpentier PA (1996) Precipitating factors for delirium in hospitalized elderly persons. Predictive model and interrelationship with baseline vulnerability JAMA 275:852-857

23. Fotenos AF, Mintun MA, Snyder AZ, Morris JC, Buckner RL (2008) Brain volume decline in aging: evidence for a relation between socioeconomic status, preclinical Alzheimer disease, and reserve. Arch Neurol 65:113-120

24. Good CD, Johnsrude IS, Ashburner J, Henson RN, Friston KJ, Frackoviak RS (2001) A voxel-based morphometric study of ageing in 465 normal adult human brains. Neuroimage 14:21-36

25. Coleman PD, Flood DG (1987) Neuron numbers and dendritic extent in normal aging and Alzheimer's disease. Neurobiol Aging 8:521-545

26. Hof PR, Morrison JH (2004) The aging brain: morphomolecular senescence of cortical circuits. Trends Neurosci 27:607-612

27. Peters A, Sethares C, Luebke JI (2008) Synapses are lost during aging on the primate prefrontal cortex. Neuroscience 152:970 981

28. Terry DR, DeTeresa R, Hansen LA (1987) Neocortical cell counts in normal human adult aging. Ann Neurol 21:530-539

29. Adalbert R, Coleman MP (2013) Axon pathology in age-related neurodegenerative disorders. Neuropathol Appl Neurobiol 39:90 108

30. Marner L, Nyengaard JR, Tang Y, Pakkenberg B (2003) Marked loss of myelinated nerve fibers in the human brain with age. $\mathrm{J}$ Comp Neurol 462:144-152

31. Burke SN, Barnes CA (2006) Neural plasticity in the ageing brain. Nat Rev Neurosci 7:30-40

32. Pannese E (2011) Morphological changes in nerve cells during normal aging. Brain Struct Funct 216:85-89

33. Juraska JM, Lowry NC (2012) Neuroanatomical changes associated with cognitive aging. Curr Top Behav Neurosci 10:137-162

34. Grillo FW (2016) Long live the axon. Parallels between ageing and pathology from a presynaptic point of view. J Chem Neuroanat 76:28-34

35. Kovacs GG, Milenkovic I, Wöhrer A, Höftberger R, Gelpi E, Haberler C, Hönigschnabel S, Reiner-Concin A, Heinzl H, Jungwirth S, Krampla W, Fischer P, Budka H (2013) NonAlzheimer neurodegenerative pathologies and their combinations are more frequent than commonly believed in the elderly brain: a community-based autopsy series. Acta Neuropathol 126:365-384 
36. Salat DH (2011) The declining infrastructure of the aging brain. Brain Connect 1:279-293

37. Kochunov P, Ramage AE, Lancaster JL, Robin DA, Narayama S, Coyle T, Royall DR, Fox P (2009) Loss of cerebral white matter structural integrity tracks the gray matter metabolic decline in normal aging. Neuroimage 45:17-28

38. Salthouse TA (2011) Neuroanatomical substrates of age-related cognitive decline. Psychol Bull 137:753-784

39. Bugiani $\mathrm{O}(2020)$ The puzzle of preserved cognition in the oldest old. Neurol Sci 41:441-447

40. Meynert T (1890) Amentia, der Vervirrtheit. Jb Psychiat 9:1-112

41. Bonhoeffer K (1908) Zur Frage der Klassifikation der symptomatischen Psychosen. Berl Klin Wschr 45:2257-2260

42. Lipowski ZJ (1967) Delirum, clouding of consciousness and confusion. J Nerv Ment Dis 145:227-255

43. Plum F, Posner JB (1980) The diagnosis of stupor and coma, 3rd edn. Davis, Philadelphia

44. Leonard M, Adamis D, Saunders J, Trzepacz P, Meagher D (2015) A longitudinal study of delirium phenomenology indicates widespread neural dysfunction. Palliat Support Care 13:187-196

45. Jacobson S, Jerrier H (2000) EEG in delirium. Semin Clin Neuropsychiatry 5:86-92

46. Kimchi EY, Neelagiri A, Whitt W, Sagi AR, Ryan SI, Gadbois G, Groothuysen D, Westover MB (2019) Clinical EEG slowing correlates with delirium severity and predicts poor clinical outcomes. Neurology 93:e1260-e1271

47. Yokota H, Ogawa S, Kurokawa A, Yamamoto Y (2003) Regional blood flow in delirium patients. Psychiatry Clin Neurosci 57:337339

48. Fong TG, Bogardus ST Jr, Daftary A, Auerbach E, Blumenfeld H, Modur S, Leo-Summers L, Seibyl J, Inouye SK (2006) Cerebral perfusion changes in older delirious patients using $99 \mathrm{mTc}$ HMPAO SPECT. J Gerontol A Biol Sci Med Sci 61:1294-1299

49. McLott J, Jurecic J, Hemphill L, Dunn KS (2013) Development of an amygdalocentric neurocircuitry-reactive aggression theoretical model of emergence delirium in posttraumatic stress disorder: an integrative literature review. AANA J 81:379-384

50. Cavallari M, Dai W, Guttmann CR, Meier DS, Ngo LH, Hshiech TT, Callahan AE, Fong TG, Schmitt E, Dickerson BC, Press DZ, Marcantonio ER, Jones RN, Inouye SK, Alsop DC, SAGES Study Group (2016) Neural substrates of vulnerability to postsurgical delirium as revealed by presurgical diffusion MRI. Brain 139: $1282-1294$

51. Trzepacz PT (1999) Update on the neuropathogenesis of delirium. Dement Geriatr Cogn Disord 10:330-334

52. Fox MD, Snyder AZ, Vincent JL, Corbetta M, Van Essen DC, Raichle ME (2005) The human brain is intrinsically organized into dynamic, anticorrelated functional networks. Proc Natl Acad Sci USA 102:9673-9678

53. Sanders RD (2011) Hypothesis for the pathophysiology of delirium: role of baseline brain network connectivity and changes in inhibitory tone. Med Hypotheses 77:140-143

54. Choi SH, Lee H, Chung TS, Park KM, Jung YC, Kim SI, Kim JJ (2012) Neural network functional connectivity during and after an episode of delirium. Am J Psychiatry 169:498-507

55. Joëls M (2011) Impact of glucocorticoids on brain functions: relevance for mood disorders. Psychoneuroendocrinology 36:406414

56. Lupien SJ, Juster RP, Raymond C, Marin MF (2018) The effects of chronic stress on the human brain: From neurotoxicity, to vulnerability, to opportunity. Front Neuroendocrinol 49:91-10557

57. Bishop NA, Lu T, Yankner BA (2010) Neural mechanisms of ageing and cognitive decline. Nature 464:529-535

58. Gaffey AE, Bergeman CS, Clark LA, Wirth MM (2016) Aging and the HPA axis: stress and resilience in older adults. Neurosci Biobehav Rev 68:928-945
59. MacLullich AM, Ferguson KJ, Miller T, de Rooij SE, Cunningham C (2008) Unravelling the pathophysiology of delirium: a focus on the role of aberrant stress responses. J Psychosom Res 65:229-238

60. White S (2002) The neuropathogenesis of delirium. Rev Clin Gerontol 12:62-67

61. Lipowski ZJ (1990) Delirium: acute confusional states. Oxford University Press, Oxford

62. Itil T, Fink M (1966) Anticholinergic drug-induced delirium: experimental modification, quantitative EEG and behavioral correlations. J Nerv Ment Dis 143:492-507

63. Guo Y, Zhang Y, Jia P, Wang W, Zhou Q, Sun L, Zhao A, Zhang X, Wang X, Li Y, Zhang J, Jiang W (2017) Preoperative serum metabolites are associated with postoperative delirium in elderly hip-fracture patients. J Gerontol A Biol Sci Med Sci 72:16891696

64. Maldonado JR (2008) Delirium in the acute care setting: characteristics, diagnosis, and treatment. Crit Care Clin 24:657-722

65. McGeer PL, McGeer EG, Suzuki JS (1977) Aging and extrapyramidal function. Arch Neurol 34:33-35

66. Bugiani O, Salvarani S, Perdelli F, Mancardi GL, Leonardi A (1978) Nerve cell loss with aging in the putamen. Eur Neurol 17:286-291

67. Volkow ND, Wang GJ, Fowler JS, Ding YS, Gur RC, Gatley J, Logan J, Moberg PJ, Hitzemann R, Smith G, Pappas N (1998) Parallel loss of presynaptic and postsynaptic dopamine markers in normal aging. Ann Neurol 44:143-147

68. Dijk DJ, Duffy JF, Riel E, Shanahan TL, Czeisler CA (1999) Ageing and the circadian and homeostatic regulation of human sleep during forced desynchrony of rest, melatonin, and temperature rhythms. J Physiol 516:611-627

69. Kim JH, Duffy JF (2018) Circadian rhythm sleep-wake disorders in older adults. Sleep Med Clin 13:39-50

70. Pandi-Perumal SR, Zisapel N, Srinivasan V, Cardinali DR (2005) Melatonin and sleep in aging population. Exp Gerontol 40:911925

71. Balan S, Leibovitz A, Zila SO, Ruth M, Chana W, Yassica B, Rahel B, Richard G, Neumann E, Blagman B, Habot B (2003) The relation between the clinical subtypes of delirium and the urinary level of 6-SMT. J Neuropsychiatr Clin Neurosci 15:363366

72. Zhong HH, Yu B, Luo D, Yang LY, Zhang J, Jiang SS, Hu SJ, Luo YY, Yang MW, Hong FF, Yang SL (2019) Roles of aging in sleep. Neurosci Biobehav Rev 98:177-184

73. Cardinali DP, Pévert P (1998) Basic aspects of melatonin action. Sleep Med Rev 2:175-190

74. McEwen BS, Karatsoreos IN (2015) Sleep deprivation and circadian disruption. Stress, allostasis, and allostatic load. Sleep Med Clin 10:1-10

75. Zisapel N (2018) New perspectives on the role of melatonin in human sleep, circadian rhythms and their regulation. Br J Pharmacol 175:3190-3199

76. Stoquart-ElSankari S, Balédent O, Gondry-Jouet C, Makki M, Godefroy O, Meyer ME (2007) Aging effects on cerebral blood and cerebrospinal fluid flows. J Cereb Blood Flow Metab 27: $1563-1572$

77. Amin-Hanjani S, Du X, Pandey DK, Thulborn KR, Charbel FT (2015) Effect of age and vascular anatomy on blood flow in major cerebral vessels. J Cereb Blood Flow Metab 35:312-318

78. Zhang N, Gordon ML, Goldberg TE (2017) Cerebral blood flow measured by arterial spin labeling MRI at resting state in normal aging and Alzheimer's disease. Neurosci Biobehav Rev 72:168175

79. Peterson EC, Wang Z, Britz G (2011) Regulation of cerebral blood flow. Int J Vasc Med doi 2011:1-8. https://doi.org/10. $1155 / 2011 / 823525$ 
80. Okhotin VE, Kalinichenko SG (2003) Subcortical white matter interstitial cells: their connections, neurochemical specialization, and role in the histogenesis of the cortex. Neurosci Behav Physiol 33:177-194

81. Drake CT, Iadecola C (2006) The role of neuronal signaling in controlling cerebral blood flow. Brain Lang 102:141-152

82. Kalaria RN (1996) Cerebral vessels in ageing and Alzheimer's disease. Pharmacol Ther 72:193-214

83. Duncombe J, Lennent RJ, Jansen MA, Marshall I, Wardlaw JM, Horsburgh K (2017) Ageing causes prominent neurovascular dysfunction with loss of astrocytic contacts and gliosis. Neuropathol Appl Neurobiol 43:477-491

84. Brown WR, Thore CR (2011) Review: cerebral microvascular pathology in ageing and neurodegeneration. Neuropathol Appl Neurobiol 37:56-74

85. Craggs LJ, Yamamoto Y, Deramecourt V, Kalaria RN (2014) Microvascular pathology and morphometrics in sporadic and hereditary small vessel diseases of the brain. Brain Pathol 24:495509

86. Lammie GA (2000) Pathology of small vessel stroke. Br Med Bull 56:296-306

87. Tarumi T, Ayaz Khan M, Liu J, Tseng BY, Parker R, Riley J, Tinajero C, Zhang R (2014) Cerebral hemodynamics in normal aging: central artery stiffness, wave reflection, and pressure pulsatility. J Cereb Blood Flow Metab 34:971-978

88. O'Rourke MF (2007) Arterial aging: pathophysiological principles. Vasc Med 12:329-341

89. Scuteri A, Nilsson PM, Tzourio C, Redon J, Laurent S (2011) Microvascular brain damage with aging and hypertension: pathophysiological consideration and clinical implications. J Hypertens 29:1469-1477

90. Harukuni I, Bhardwai A (2006) Mechanisms of brain injury after global cerebral ischemia. Neurol Clin 24:1-21

91. Riddle DR, Sonntag WE, Lichtenwalner RJ (2003) Microvascular plasticity in aging. Ageing Res Rev 2:149-168

92. Hatano Y, Narumoto J, Shibata K, Matsuoka T, Tamiguchi S, Hata Y, Yamada K, Yaku H, Fukui K (2013) White-matter hyperintensities predict delirium after cardiac surgery. Am J Geriatr Psychiatry 21:938-945

93. Otomo S, Maekawa K, GotoT BT, Yoshitake A (2013) Preexisting cerebral infarcts as a risk factor for delirium after coronary artery bypass graft surgery. Interact Cardiovasc Thorac Surg 17: 799-804

94. Root JC, Pryor KO, Downey R, Alici Y, Davis ML, Holodni A, Korc-Grodzicki B, Ahles T (2013) Association of pre-operative brain pathology with post-operative delirium in a cohort of nonsmall cell lung cancer patients undergoing surgical resection. Psychooncology 22:2087-2094

95. Cavallari M, Hshieh TT, Guttmann CR, Ngo LH, Meier DS, Schmitt EM, Marcantonio ER, Jones RN, Kosar CM, Fong TG, Press D, Inouye SK, Alsop DC, SAGES Study Group (2015) Brain atrophy and white-matter hyperintensities are not significantly associated with incidence and severity of postoperative delirium in older persons without dementia. Neurobiol Aging 36: 2122-2129

96. Hshieh TT, Dai W, Cavallari M, Guttmann CR, Meier DS, Schmitt EM, Dickerson BC, Press DZ, Marcantonio ER, Jones RN, Gou YR, Travison TG, Fong TG, Ngo L, Inouye SK, Alsop DC, SAGES Study Group (2017) Cerebral blood flow MRI in the nondemented elderly is not predictive of post-operative delirium but is correlated with cognitive performances. J Cereb Blood Flow Metab 37:1386-1397

97. Schoen J, Meyerrose J, Paarmann H, Heringlake M, Hueppe M, Berger KU (2011) Preoperative regional cerebral oxygen saturation is a predictor of postoperative delirium in on-pump cardiac surgery patients: a prospective observational trial. Crit Care 15: R218. https://doi.org/10.1186/cc10454

98. Daneman R, Prat A (2015) The blood-brain barrier. Cold Spring Harb Perspect Biol 7:a020412. https://doi.org/10.1101/ cshperspect.a020412

99. Hawkins BT, Davis TP (2005) The blood-brain barrier/ neurovascular unit in health and disease. Pharmacol Rev 57: 173-185

100. Abbott NJ, Rönnbäck L, Hansson E (2006) Astrocyte-endothelial interactions at the blood-brain barrier. Nat Rev Neurosci 7:41-53

101. Keaney J, Campbell M (2015) The dynamic blood-brain barrier FEBS J 282:4067-4079

102. Bazargani N, Attwell D (2016) Astrocyte calcium signaling: the third wave. Nat Neurosci 19:182-189

103. Hall CN, Reynell C, Gesslein B, Hamilton NB, Mishra A, Sutherland BA, O'Farrell FM, Buchan AM, Lauritzen M, Attwell D (2014) Capillary pericytes regulate cerebral blood flow in health and disease. Nature 508:55-60

104. Erickson MA, Banks WA (2019) Age-associated changes in the immune system and blood-brain barrier functions. Int J Mol Sci 20:1632. https://doi.org/10.3390/ijms20071632

105. Hartz AM, Bauer B, Soldner EL, Wolf A, Boy S, Backhaus R, Mihaljevic I, Bogdahn U, Klünemann HH, Schuierer G, Schlachetzki F (2012) Amyloid- $\beta$ contributes to blood-brain barrier leakage in transgenic human amyloid precursor protein mice and in humans with cerebral amyloid angiopathy. Stroke 43:514 523

106. Farrall AJ, Wardlaw JM (2009) Blood-brain barrier: ageing and microvascular disease - systematic review and meta-analysis. Neurobiol Aging 30:337-352

107. Senatorov VV Jr, Friedman AR, Milikowski DZ, Ofer J, SaarAshkenazy R, Charbash A, Jahan N, Chin G, Mihaly E, Lin JM, Ramsay HJ, Moghbel A, Preininger MK, Eddings CR, Harrison HV, Patel R, Shen Y, Ghanim H, Sheng H, Veksler R, Sudmant PH, Becker A, Hart B, Rogawski MA, Dillin A, Friedman A, Kaufer D (2019) Blood-brain barrier dysfunction in aging induces hyper-activation of TGF-beta signaling and chronic yet reversible neural dysfunction. BioRxiv. https://doi.org/10.1101/537431

108. Chen CP, Chen RL, Preston JE (2012) The influence of ageing in the cerebrospinal fluid concentrations of proteins that are derived from the choroid plexus, brain, and plasma. Exp Gerontol 47:323328

109. Montagne A, Barnes SR, Sweeney MD, Halliday MR, Sagare AP, Zhao Z, Toga AW, Jacobs RE, Liu CY, Amezcua L, Harrington MG, Chui HC, Law M, Zlokovic BV (2015) Blood-brain barrier breakdown in the aging human hippocampus. Neuron 85:296-302

110. Nation DA, Sweeney MD, Montagne A, Sagare AP, D'Orazio LM, Pachicano M, Sepehrband F, Nelson AR, Buennagel DP, Harrington MG, Benzinger TLS, Fagan AM, Ringman JM, Schneider LS, Morris JC, Chui HC, Law M, Toga AW, Zlokovic BV (2019) Blood-brain barrier breakdown is an early biomarker of human cognitive dysfunction. Nat Med 25:270-276

111. Erdö F, Denes L, de Lange E (2017) Age-associated physiological and pathological changes at the blood-brain barrier: a review. J Cereb Blood Flow Metab 37:4-24

112. Varatharaj A, Galea I (2017) The blood-brain barrier in systemic inflammation. Brain Behav Immun 60:1-12

113. Acharya NK, Goldwaser EL, Forsberg MM, Godsey GA, Johnson CA, Sarkar A, DeMarshall C, Kosciuk MC, Dash JM, Hale CP, Leonard DM, Appelt DM, Nagele RG (2015) Sevoflurane and Isoflurane induce structural changes in brain vascular endothelial cells and increase blood-brain barrier permeability: possible link to postoperative delirium and cognitive decline. Brain Res 1620:29 41

114. Johanson C, Silverberg G, Donahue J, Duncan J, Stopa E (2004) Choroid plexus and CSF in Alzheimer's disease: altered 
expression and transport of proteins and peptides. In: Zheng W, Chodobski A (eds) The blood-cerebrospinal fluid barrier. CRC Press, Boca Raton, pp 307-339

115. Johanson CE, Duncan JA 3rd, Klinge PM, Brinker T, Stopa EG, Silverberg GD (2008) Multiplicity of cerebrospinal fluid functions: new challenges in health and disease. Cerebrospinal Fluid Res 5:10. https://doi.org/10.1186/1743-8454-5-10

116. Rubenstein E (1998) Relationship of senescence of cerebrospinal fluid circulatory system to dementias of the aged. Lancet 351:383385

117. Silverberg GD, Mayo M, Saul T, Rubenstein E, McGuire D (2003) Alzheimer's disease, normalpressure hydrocephalus, and senescent changes in CSF circulatory physiology: a hypothesis. Lancet Neurol 2:506-511

118. Hassan I, Shing C, Bajraszewski CE, Gleason A, Hayhow BD, Velakoulis D (2013) Osmotic demyelination syndrome: an underrecognised cause of delirium? Aust N Z J Psychiatry 47:287-288

119. Trillo-Contreras JL, Ramírez-Lorca R, Hiraldo-González L, Sánchez-Gomar I, Galán-Cobo A, Suárez-Luna N, Sánchez de Rojas-de Pedro E, Toledo-Aral JJ, Villadiego J, Echevarría M (2018) Combined effects of aquaporin-4 and hypoxia produce age-related hydrocephalus. Biochem Biophys Acta Mol Basis Dis 1864:3515-3526

120. Filippidis AS, Carozza RB, Rekate HL (2016) Aquaporins in brain edema and neuropathological conditions. Int J Mol Sci 18:55. https://doi.org/10.3390/ijms18010055

121. Nedergaard M (2013) Neuroscience. Garbage truck of the brain Science 340:1529-1530

122. Benveniste H, Liu X, Koundal S, Sanggaard S, Lee H, Wardlaw J (2019) The glymphatic system and waste clearance with brain aging: a review. Gerontology 65:106-119

123. Redzic ZB, Preston JE, Duncan JA, Chodobski A, SzmydyngerChodobska J (2005) The choroid plexus-cerebrospinal fluid system: from development to aging. Curr Top Dev Biol 71:1-52

124. Shibata M, Yamada S, Kumar SR, Calero M, Bading J, Frangione B, Holtzman DM, Miller CA, Strickland DK, Ghiso J, Zlokovic BV (2000) Clearance of Alzheimer's amyloid- $\beta 1-40$ peptide from brain by LDL receptor-related protein-1 at the blood-brain barrier. J Clin Invest 106:1489-1499

125. Deane R, Du Yan S, Submamaryan RK, LaRue B, Jovanovic S, Hogg E, Welch D, Manness L, Lin C, Yu J, Zhu H, Ghiso J, Frangione B, Stern A, Schmidt AM, Armstrong DL, Arnold B, Liliensiek B, Nawroth P, Hofman F, Kindy M, Stern D, Zlokovic B (2003) RAGE mediates amyloid- $\beta$ peptide transport across the blood-brain barrier and accumulation in brain. Nat Med 9:907913

126. Crossgrove JS, Li GJ, Zheng W (2005) The choroid plexus removes $\beta$-amyloid from brain cerebrospinal fluid. Exp Biol Med (Maywood) 230:771-776

127. Donahue JE, Flaherty SL, Johanson CE, Duncan JA 3rd, Silverberg GD, Miller MC, Tavares R, Yang W, Wu Q, Sabo E, Hovanesian V, Stopa EG (2006) RAGE, LRP-1, and amyloidbeta protein in Alzheimer's disease. Acta Neuropathol 112:405415

128. Li L, Zhang X, Yang D, Luo G, Chen S, Le W (2009) Hypoxia increases $A \beta$ generation by altering $\beta$ - and $\gamma$-cleavage of APP. Neurobiol Aging 30:1091-1098

129. Guglielmotto M, Aragno M, Autelli R, Giliberto L, Novo E, Colombatto S, Danni O, Parola M, Smith MA, Perry G, Tamagno E, Tabaton M (2009) The up-regulation of BACE1 mediated by hypoxia and ischemic injury: role of oxidative stress and HIF $1 \propto$. J Neurochem 108:1045-1056

130. Bulbarelli A, Lonati E, Brambilla A, Orlando A, Cazzaniga E, Piazza F, Ferrarese C, Masserini M, Sancini G (2012) A $\beta 42$ production in brain capillary endothelial cells after oxygen and glucose deprivation. Mol Cell Neurosci 49:415-422
131. Branger P, Arenaza-Urquijo EM, Tomadesso C, Mézenge F, André C, de Flores R, Mutlu J, de la Sayette V, Eustache F, Chételat G, Rauchs G (2016) Relationships between sleep quality and brain volume, metabolism, and amyloid deposition in late adulthood. Neurobiol Aging 41:107-114

132. You JC, Jones E, Cross DE, Lyon AC, Kang H, Newberg AB, Lippa CF (2019) Association of $\beta$-amyloid burden with sleep dysfunction and cognitive impairment in elderly individuals with cognitive disorders. JAMA New Open 2:e1913383. https://doi. org/10.1001/jamanetworkopen.2019.13383

133. Serot JM, Christmann D, Dubost T, Couturier M (1997) Cerebrospinal fluid transthyretin: aging and late onset Alzheimer's disease. J Neurol Neurosurg Psychiatry 63:506-508

134. Payne BA, Chinnery PF (2015) Mitochondrial dysfunction in aging: much progress but many unsolved questions. Biochim Biophys Acta 1847:1347-1353

135. Harman D (1956) Aging: a theory based on free radical and radiation chemistry. J Gerontol 11:298-300

136. Catic A (2018) Cellular metabolism and aging. Prog Mol Biol Transl Sci 155:85-107

137. Karlidag R, Unal S, Sezer OH, Bay Karabulut A, Battaloğlu B, But A, Ozcan C (2006) The role of oxidative stress in postoperative delirium. Gen Hosp Psychiatry 28:418-423

138. Eertmans W, De Deyne C, Genbrugge C, Marcus B, Bouneb S, Beran M, Fret T, Gutermann H, Boer W, Vander Laenen M, Heylen R, Mesotten D, Vanelderen P, Jans F (2020) Association between postoperative delirium and postoperative cerebral oxygen desaturation in older patients after cardiac surgery. Br J Anaesth 124:146-153

139. Ross JM, Öberg J, Brené S, Coppotelli G, Terzioglu M, Pernold K, Goiny M, Sitnikov R, Kehr J, Trifunovic A, Larsson NG, Hoffer BJ, Olson L (2010) High brain lactate is a hallmark of aging and caused by a shift in the lactate dehydrogenase $\mathrm{A} / \mathrm{B}$ ratio. Proc Natl Acad Sci USA 107:20087-20092

140. Grimm A, Eckert A (2017) Brain aging and neurodegeneration: from a mitochondrial point of view. J Neurochem 143:418-431

141. Jiang T, Cadenas E (2014) Astrocytic metabolic and inflammatory changes as a function of age. Aging Cell 13:1059-1067

142. Franceschi C, Bonafé M, Valensin S, Olivieri F, De Luca M, Ottaviani E, De Benedictis G (2000) Inflammaging. An evolutionary perspective on immunosenescence. Ann N Y Acad Sci 908: 244-254

143. Fonken LK, Frank MG, Gaudet AD, Maier SF (2018) Stress and aging act through common mechanisms to elicit neuroinflammatory priming. Brain Behav Immun 73:133-148

144. Cornejo F, von Bernhardi R (2016) Age-dependent changes in the activation and regulation of microglia. Adv Exp Med Biol 949: 205-226

145. Udeochu JC, Shea JM, Villeda SA (2016) Microglia communication: parallels between aging and Alzheimer's disease. Clin Exp Neuroimmunol 7:114-125

146. Tay TL, Savage JC, Hui CW, Bisht K, Tremblay MÈ (2017) Microglia across the lifespan: from origin to function in brain development, plasticity and cognition. J Physiol 595:1929-1945

147. Wolf SA, Boddeke HW, Kettenmann H (2017) Microglia in physiology and disease. Annu Rev Physiol 79:619-643

148. Streit WJ, Xue QS (2010) The brain's aging immune system. Aging Dis 1:254-261

149. Damani MR, Zhao L, Fontainhas AM, Amaral J, Fariss RN, Wong WT (2011) Age-related alterations in the dynamic behavior of microglia. Aging Cell 10:263-276

150. Niraula A, Sheridan JF, Godbout JP (2017) Microglia priming with aging and stress. Neuropsychopharmacology 42:318-333

151. Bachstetter AD, Ighodaro ET, Hassoun Y, Aldeiri D, Neltner JH, Patel E, Abner EL, Nelson PT (2017) Rod-shaped microglia 
morphology is associated with aging in 2 human autopsy series. Neurobiol Aging 52:98-105

152. Bisht K, Sharma KP, Lecours C, Sánchez MG, El Hajj H, Milior G, Olmos-Alonso A, Gómez-Nicola D, Luheshi G, Vallières L, Branchi I, Maggi L, Limatola C, Butovsky O, Tremblay MÈ (2016) Dark microglia: a new phenotype predominantly associated with pathological states. Glia 64:826-839

153. Ravji KS, Mishra MK, Michaels NJ, Rivest S, Stys PK, Yong VW (2016) Immunosenescence of microglia and macrophages: impact of the ageing central nervous system. Brain 139:653-661

154. Uchikado H, Akiyama H, Kondo H, Ikeda K, Tsushiya K, Kato M, Oda T, Togo T, Iseki E, Kosaka K (2004) Activation of vascular endothelial cells and perivascular cells by systemic inflammation - an immunohistochemical study of postmortem human brain tissues. Acta Neuropathol 107:341-351

155. Perry VH, Holmes C (2014) Microglial priming in neurodegenerative diseases. Nat Rev Neurol 10:217-224

156. Safaiyan S, Kannaiyan N, Snaidero N, Brioschi S, Biber K, Yona S, Edinger AL, Jung S, Rossner MJ, Simons M (2016) Agerelated myelin degradation burdens the clearance function of microglia during aging. Nat Neurosci 19:995-998

157. Piva S, McCreadie VA, Latronico N (2015) Neuroinflammation in sepsis: sepsis associated delirium. Cardiovasc Hematol Disord Drug Targets 15:10-18

158. Johanson A, Olsson T, Carlberg B, Karlsson K, Fagerlund M (1997) Hypercorticolism after stroke - partly cytokine-mediated? J Neurol Sci 147:43-47

159. Cerejeira J, Lagarto L, Mukaetova-Ladinska EB (2014) The immunology of delirium. Neuroimmunomodulation 21:72-78

160. Dantzer R, O'Connor JC, Freund GG, Johnson RW, Kelley KW (2008) From inflammation to sickness and depression: when the immune system subjugates the brain. Nat Rev Neurosci 9:46-56

161. van Gool WA, van de Beek D, Eikelenboom P (2010) Systemic infection and delirium: when cytokines and acetylcholine collide. Lancet 375:773-775

162. van Munster BC, Bisschop PH, Zwinderman AH, Korevaar JC, Endert E, Wiersinga WJ, van Oosten HE, Goslings JC, de Rooij SE (2010) Cortisol, interleukins and S100B in delirium in the elderly. Brain Cogn 74:18-23

163. Westhoff D, Witlox J, Koenderman L, Kalisvaart KJ, de Jonghe JF, van Stijn MF, Houdijk AP, Hoogland IC, Maclullic AM, van Westerloo DJ, van de Beek D, Eikelenboom P, van Gool WA (2013) Preoperative cerebrospinal fluid cytokine levels and the risk of postoperative delirium in elderly hip fracture patients. J Neuroinflammation 10:122. https://doi.org/10.1186/1742-2094$10-122$

164. Vasunilashom SM, Ngo L, Inouye SK, Libermann TA, Jones RN, Alsop DC, Guess J, Jastrzebski S, McElhaney JE, Kuchel GA, Marcantonio ER (2015) Cytokines and postoperative delirium in older patients undergoing major elective surgery. J Gerontol A Biol Sci Med Sci 70:1289-1295

165. Hirsch J, Vacas S, Terrando N, Yuan M, Sands LP, Kramer J, Bozic K, Maze MM, Leung JM (2016) Perioperative cerebrospinal fluid and plasma inflammatory markers after orthopedic surgery. J Neuroinflammation 13:211. https://doi.org/10.1186/ s12974-016-0681-9

166. Kowalska K, Klimiec E, Weglarczyk K, Pera J, Slowik A, Siedlar M, Dziedzic T (2018) Reduced ex vivo release of proinflammatory cytokines and elevated plasma interleukin-6 are inflammatory signatures of post-stroke delirium. J Neuroinflammation 15:111. https://doi.org/10.1186/s12974-0181156-y

167. Conti E, Andreoni S, Tomaselli D, Storti B, Brovelli F, Acampora R, Da Re F, Apollonio I, Ferrarese C, Tremolizzo L (2020) Serum DBI and biomarkers of neuroinflammation in Alzheimer's disease and delirium. Neurol Sci 42:1003-1007. https://doi.org/10.1007/ s10072-020-04608-X

168. van Munster BC, Aronica E, Zwinderman AH, Eikelenboom P, Cunningham C, de Rooij SE (2011) Neuroinflammation in delirium: a postmortem case-control study. Rejuvenation Res 14:615622

169. Beloosesky Y, Hendel D, Weiss A, Hershkovicz A, Grinblat J, Pirotsky A, Barak V (2007) Cytokines and C-reactive protein production in hip-fracture-operated elderly patients. J Gerontol A Biol Sci Med Sci 62:420-426

170. de Rooij SE, van Munster BC, Korevaar JC, Levi M (2007) Cytokines and acute phase response in delirium. J Psychosom Res 62:521-525

171. Cape E, Hall RJ, van Munster BC, de Vries A, Howie SE, Pearson A, Middleton SD, Gillies F, Armstrong IR, White TO, Cunningham C, de Rooij SE, MacLullich AM (2014) Cerebrospinal fluid markers of neuroinflammation in delirium: a role for interleukin- $1 \beta$ in delirium after hip fracture. J Psychosom Res 77:219-225

172. Neerland BE, Hall RJ, Seljeflot I, Frihagen F, MacLullich AM, Raeder J, Wyller TB, Watne LO (2016) Associations between delirium and preoperative cerebrospinal fluid C-reactive protein, interleukin-6, and interleukin-6 receptor in individuals with acute hip fracture. J Am Geriatr Soc 64:1456-1463

173. Slor CJ, Witlox J, Adamis D, Jansen RW, Houdijk AP, van Gool WA, de Jonghe JF, Eikelenboom P (2019) The trajectory of Creactive protein serum levels in older hip fracture patients with postoperative delirium. Int J Geriatr Psychiatr 34:1438-1446

174. Sajjat MU, Blennow K, Knapskog AB, Idland AV, Chaudhry FA, Wyller TB, Zetterberg H, Watne LO (2020) Cerebrospinal fluid levels of interleukin- 8 in delirium, dementia, and cognitively healthy patients. J Alzheimers Dis 73:1363-1372

175. Simons KS, van den Boogaard M, Hendriksen E, Gerretsen J, van der Hoeven JG, Pickkers P, de Jager CPC (2018) Temporal biomarker profiles and their association with ICU acquired delirium: a cohort study. Crit Care 22:137. https://doi.org/10.1186/s13054018-2054-5

176. Jackson JC, Gordon SM, Hart RP, Hopkins RO, Ely EW (2004) The association between delirium and cognitive decline: a review of the empirical literature. Neuropsychol Rev 14:87-98

177. MacLullich AM, Beaglehole A, Hall RJ, Meagher DJ (2009) Delirium and long-term cognitive impairment. Int Rev Psychiatry 21:30-42

178. Goldberg TE, Chen C, Wang Y, Jung E, Swanson A, Ing C, Garcia PS, Whittington RA, Moitra V (2020) Association of delirium with long-term cognitive decline. A meta-analysis JAMA Neurol 77:1-9

179. Gross AL, Jones RN, Haltemariam DA, Fong TG, Tammet D, Quach L, Schmitt E, Yap L, Inouye SK (2012) Delirium and long-term cognitive trajectory among persons with dementia. Arch Intern Med 172:1324-1331

180. Weiner MF (2012) Impact of delirium on the course of Alzheimer disease. Arch Neurol 69:1639-1640

181. Davis DH, Muniz-Terrera G, Keage H, Rahkonen T, Oinas M, Matthews FE, Cunningham C, Polvikoski T, Sulkava R, MacLullich AM, Brayne C (2012) Delirium is a strong risk factor for dementia in the oldest-old: a population-based cohort study. Brain 135:2809-2816

182. Davis DH, Muniz-Terrera G, Keage HA, Stephan BC, Fleming J, Ince PG, Matthews FE, Cunningham C, Ely EW, MacLullick AMJ, Brayne C, Epidemiological Clinicopathological Studies in Europe (EClipSE) Collaborative Members (2017) Association of delirium with cognitive decline in late life. A neuropathologic study of 3 population-based cohort studies. JAMA Psychiatry $74: 244-251$ 
183. Erten-Lyons D, Dodge HH, Woltjer R, Silbert LC, Howieson DB, Kramer P, Kaye JA (2013) Neuropathologic basis of ageassociated brain atrophy. JAMA Neurol 70:616-622

184. Xekardaki A, Kövari E, Gold G, Papadimitropoulou A, Giacobini E, Herrmann F, Giannakopoulos P, Bouras C (2015) Neuropathological changes in aging brain. Adv Exp Med Biol 821:11-17

185. Fotuhi M, Mian A, Meysami S, Raji CA (2020) Neurobiology of COVID-19. J Alzheimers Dis 76:3-19

186. Mirfazeli FS, Sarabi-Jamab A, Jahanbakhshi A, Kordi A, Javadnia P, Shariat SV, Aloosh O, Almasi-Dooghaee M, Faiz SH (2020) Neuropsychiatric manifestations of COVID-19 can be clustered in three distinct symptom categories. Sci Rep 10:20957. https://doi. org/10.1038/s41598-020-78050-6

187. Sharshar T, Carlier R, Bernard F, Guidoux C, Brouland JP, Nardi O, de la Grandmaison GL, Aboab J, Gray F, Menon D, Annane D (2007) Brain lesions in septic shock: a magnetic resonance imaging study. Intensive Care Med 33:798-806

188. Morandi A, Rogers BP, Gunther ML, Merkle K, Pandharipande P, Girard TD, Jackson JC, Thompson J, Shintani AK, Geevarghese S, Miller RR 3rd, Canonico A, Cannistraci CJ, Gore JC, Ely EW, Hopkins RO, VISIONS investigation, VISualizing Icu SurvivOrs Neuroradiological Sequelae (2012) The relationship between delirium duration, white matter integrity, and cognitive impairment in intensive care unit survivors as determined by diffusion tensor imaging: the VISIONS prospective cohort magnetic resonance imaging study. Crit Care Med 40:2182-2189

189. Cavallari M, Dai W, Guttmann CR, Meier DS, Ngo LH, Hshieh TT, Fong TG, Schmitt E, Press DZ, Travison TG, Marcantonio ER, Jones RN, Inouye SK, Alsop DC, SAGES Study Group (2017) Longitudinal diffusion changes following postoperative delirium in older people without dementia. Neurology 89:1020 1027

190. Gunther ML, Morandi A, Krauskopf E, Pandharipande P, Girard TD, Jackson JC, Thompson J, Shintani AK, Geevarghese S, Miller RR 3rd, Canonico A, Merkle K, Cannistraci CJ, Rogers
BP, Gatenby JC, Heckers S, Gore JC, Hopkins RO, Ely EW, VISIONS investigartion, VISualizing Icu SurvivOrs Neuroradiological Sequelae (2012) The association between brain volumes, delirium duration, and cognitive outcomes in intensive care unit survivors: the VISIONS cohort magnetic resonance imaging study. Clin Care Med 40:2022-2032

191. van Munster BC, Korevaar JC, Korse CM, Bonfrer JM, Zwinderman AH, de Rooij SE (2010) Serum S100B in elderly patients with and without delirium. Int J Geriatr Psychiatry 25: 234-239

192. Hatherill S, Fisher AJ (2010) Delirium in children and adolescents: a systematic review of the literature. J Psychosom Res 68: 337-344

193. Harris J, Ramelet AS, van Dijk M, Pokorna P, Wielenga J, Tume L, Tibboel D, Ista E (2016) Clinical recommendations for pain, sedation, withdrawal and delirium assessment in critically ill infants and children: an ESPNIC position statement for healthcare professionals. Intensive Care Med 42:972-986

194. Malas N, Brahmbhatt K, McDermott C, Smith A, Ortiz-Aguayo R, Turkel S (2017) Pediatric delirium: evaluation, management, and special considerations. Curr Psychiatry Rep 19:65. https://doi. org/10.1007/s11920-017-0817-3

195. Patel AK, Bell MJ, Traube C (2017) Delirium in pediatric critical care. Pediatr Clin N Am 64:1117-1132

196. Smith HA, Gangopadhyay M, Goben CM, Jakobowski NL, Chestnut MH, Savage S, Rutherford MT, Denton D, Thomson JL, Chandrasekhar R, Acton M, Newman J, Noori HP, Terrell MK, Williams SR, Griffith K, Cooper TJ, Ely EW, Fuchs DC, Pandharipande PP (2016) The preschool confusion assessment method for the ICU: valid and reliable delirium monitoring for critically ill infants and children. Crit Care Med 44:592-600

Publisher's note Springer Nature remains neutral with regard to jurisdictional claims in published maps and institutional affiliations. 